\title{
Inclusive Globalisation, Navigating the Challenges of 'Inclusivity'
}

\author{
Suraiya Hameed* \\ University of Queensland, Australia
}

Submission: January 16, 2019; Published: January 22, 2019

*Corresponding author: Suraiya Hameed, University of Queensland, St Lucia QLD 4072, Australia

Abstract

Globalisation has resulted in a profound but concerning effect on educational systems worldwide. The complexity associated with globalization has had defining effects and emotive connotations. At one end, the impact of globalization is seen as an essential component of the positive development of economic, political, social and cultural as well as environmental improvements globally. At the other end, it is seen as a source and root of contemporary tribulations, possibly contributing to segregation and alienation. This paper defines the idea of inclusivity within the globalized landscape. It discusses briefly the importance of inclusive education within the $21^{\text {st }}$ century educational systems and also deliberates on its key challenges. One of the greatest obstacle faced by educational institutions globally is maintaining the balance between the neo-liberal agenda (which focuses on the competitiveness of schools in their market contexts) [1] and the educative agenda, that emphasizes the significance of social and moral values, shared social responsibility and action [2] .

\section{Globalisation and Inclusivity}

'Globalisation and inclusivity' have been a trending concept used by researchers, to explain the shifts and changes within education systems of the 21st century to support a more inclusive society. "Inclusion would mean the end of labelling and segregated education classes, but not the end of necessary supports and services, which would follow students with special needs into the regular classroom' [3]. The need for inclusivity is set against the globalising landscape, and increasingly diverse populations within nations, otherwise understood as the condition of super-diversity.

Many countries in the world such as Britain, Canada, the USA, Australia and even Singapore, are characterised by this notion of "super-diversity" [4], a state of existence that defines the heightened level and type of demographic complexity that a country is experiencing. With complexities arising from this concept of super-diversity, concerns about the ability of countries to meet the heightened needs of their contemporary diversified population in terms of socio-economic aspects, education, health matters and other pressing needs of its current citizens have since arisen [4]. Against a super diversified social background, inclusivity or inclusive education has become a prominent concept. According to Loreman, et al. [5], inclusive education celebrates the notion of a class, which embraces students with multiple characteristics. Schools are powerful socialising agencies and appropriate avenues to promote cultural pluralism and diversity in our globalising world.

\section{Educational Reform and Inclusivity}

In recent years, educational reform has taken place, thus resulting in changes to educational policy and positioning, reframing the status of pupils and teachers within education and educational systems, Vigman (2005), Krivsenko [6]. It has been argued that such reforms are key drivers towards attaining social cohesion and integration [7]. Inclusive education has since made an impact on educational systems globally, such as the initiation of a disability anti-discrimination legislature within Australia, UK and USA, and the introduction of other inclusion policies and educational reforms that emphasize on the importance of schools' response to diversity. Steeped within such reforms is the need to pay closer attention to students of varying abilities, particularly in the area of support for those with disabilities. As a result, teachers have an integral role in supporting students during the process of inclusion. Failures to attend to this results in divisions and thus paralyses the act of inclusivity and inclusive education [8]. Within the current educational system and landscape, the special educational needs of students are integral components driving this change. As such, the school is entrusted to support inclusive education and to ensure that the knowledge gained by each student through active learning is in accordance with individual ability.

The question that remains unanswered or one that requires further investigation is " How do we maximize the positive 
effects and minimize the negative impacts of globalization, when economic growth in the last decade has resulted in exacerbating inequalities as well as inequalities towards acquisition of knowledge?" [9]. Educational policies thus take center stage in the provision of social sustainability of globalization, determining if students acquire the appropriate knowledge and skills to reap the benefits of globalisation. Despite the potential gains from the ideas that have arisen as a result of globalization, many third world countries as well as student populations with learning needs or disabilities struggle through the process of advancement and development, having been excluded from this equation. This is attributed to the lack of skills to keep up with the new advancements and technologies arising from the dynamic conditions of globalization. Simply put, students with learning disabilities face difficulties because they are not provided with suitable infrastructures and support from educators and educational institutions.

\section{Neo-Liberal Market Influences on Inclusivity}

Researchers have also shown that the present global settings seem to emphasise the competitive and marketised aspects of institutions, and moral and social development policies and agendas have sometimes taken a back seat [10-13]. According to Rizvi and Lingard [14], the neo-liberal agenda has emerged as an influential "social imaginary of globalisation." This concept of a social imaginary, as defined by Taylor [15], is the way in which people "imagine their social existence-how they fit together with others and how things go on between them and their fellows, the expectations that are normally met and the deeper normative notions and images that underlie these expectations" (p. 119). A particular conception of the social imaginary has resulted in the narrowing of the concepts of education and the common good focus and has encouraged instead an emphasis on the values associated with distinct self-interest, market efficiency and liberty, leading to the development of market priority as opposed to a common good priority [13].

Schools, in their quest for distinction within their respective market positioning, have thus focused on the idea of "social efficiency" in their development of capable and skilful individuals. This focus is thus on the development of individuals with a "strong grounding in basic literacy and numeric skills and who are flexible and creative, multiskilled, and competent in information and communication technologies" [8]. This incipient market-driven educational paradigm has critical implications for students with disabilities, those who are appear to be outliers within a homogenizing educational system. Such an exclusive educational paradigm has profound implications for those students with disabilities and inclusive education. For example, English-language learners (ELLs) have been identified as those that require special needs education due to language barrier [8].

An important factor to note with regard to inclusive education is an understanding of the changed nature of the educational landscape as a result of advancement in technology and economic growth on a global scale. As mentioned earlier, with a super diversified society, inclusivity has become a key concept. In time, inclusive education amidst globalisation, has the prospect of allowing teachers and students to explore their collective and individual identities, and cross boundaries of location in order to expand knowledge and learning. Although there exist apparent tensions between the educational and market rationales as discussed earlier, a question that requires further exploration is "How can the trends towards globalization, standardization, and the homogenization of existing models be conciliated?" Only through such conciliation, can the existing tensions within a more inclusive globalisation be attained.

\section{References}

1. Vidovich L (2004) Towards internationalizing the curriculum in a context of globalization: Comparing policy processes in two settings. Compare: A Journal of Comparative and International Education 34(4): 443-461.

2. Pais A, Costa M (2017) An ideology critique of global citizenship education. Critical Studies in Education.

3. Wade SE (2000) Inclusive education: A casebook and readings for prospective and practicing teachers. Routledge, United Kingdom.

4. Vertovec S (2007) Super-diversity and its implications. Ethnic and Racial Studies 30(6): 1024-1054.

5. Loreman T, Deppeler J, Harvey D (2005) Inclusive education: A practical guide to supporting diversity in the classroom. Psychology Press.

6. Milenovic Z (2011) Inclusive education as a consequence of the globalisation process. Metodicki obzori 6(12): 73-79.

7. Armstrong, Derrick, Armstrong, Ann Cheryl, Spandagou, et al. (2011) Inclusion: By choice or by chance? International Journal of Inclusive Education 15(1): 29-39.

8. Shaikh M, Vazir Ahmed S (2017) Role of Globalization in Inclusive Education. Scholarly Research Journal for Interdisciplinary Studies.

9. Bakhtiari S (2011) Globalization and education: Challenges and opportunities. International Business and Economics Research Journal 5(2): 95-101.

10. Khoo SM (2011) Ethical globalisation or privileged internationalisation? Exploring global citizenship and internationalisation in Irish and Canadian universities. Globalisation, Societies and Education 9(3-4): 337-353.

11. Marshall H (2011) Instrumentalism, ideals and imaginaries: Theorising the contested space of global citizenship education in schools. Globalisation, Societies and Education 9: 411-426.

12. Camicia SP, Franklin BM (2011) What type of global community and citizenship? Tangled discourses of neoliberalism and critical democracy in curriculum and its reform. Globalisation, Societies and Education 9(3-4): 311-322.

13. HameedS(2018) GlobalcitizenshipeducationinSingaporeandAustralia: A comparative study of global citizenship education and international curricula in two school settings. (Doctoral dissertation).

14. Rizvi F, Lingard B (2010) Globalizing education policy. Routledge: New York, USA.

15. Taylor C (2007) Cultures of democracy and citizen efficacy. Public Culture 19(1): 117-150. 
CC) Commons Attribution 4.0 License BY DOI: 10.19080/GJIDD.2019.06.555679
Your next submission with Juniper Publishers will reach you the below assets

- Quality Editorial service

- Swift Peer Review

- Reprints availability

- E-prints Service

- Manuscript Podcast for convenient understanding

- Global attainment for your research

- Manuscript accessibility in different formats

( Pdf, E-pub, Full Text, Audio)

- Unceasing customer service

Track the below URL for one-step submission https://juniperpublishers.com/online-submission.php 